\title{
Religious Attitudes of High School Islamic Teachers in Central Java Against Ethnicity and Differences in Faith
}

\author{
Muhammad Adnan ${ }^{1}$, Wahid Abdulrahman ${ }^{2}$, Budi Setiyono ${ }^{3}$ \\ \{wahid.abdulrahman@live.undip.ac.id ${ }^{2}$ \} \\ Universitas Diponegoro, Indonesia ${ }^{1,2,3}$
}

\begin{abstract}
The teacher is an important figure who influences the views and attitudes of students. The moderate teacher's view becomes a model for students to have the same view and vice versa. Using a descriptive quantitative approach through a survey, scattered in 14 regency and municipals, this study illustrates how the attitudes of Islamic high school teachers towards differences in ethnicity and belief. The results showed that the majority of Islamic high school/vocational school teachers in Central Java are groups of people who live amid ethnic diversity and religion or belief. They have views and attitudes that can accept ethnic differences, are willing to cooperate, have high trust in others even to people from a different ethnic background, and the ability to build a harmonious social life with different ethnicities. They have views and tolerant attitudes towards different beliefs. Willingness to live next door, cooperate, help. However, in the political field, there are different views and attitudes with a large enough percentage not to be willing to cooperate. From a national perspective, there are still views among them that do not believe in Pancasila and NKRI as the best ideology and form of the state for Indonesia.
\end{abstract}

Keywords: Attitudes, Ethnicity, Differences in Beliefs

\section{Introduction}

The teacher is an important figure who influences the views and attitudes of students so that in the end they can form habits that eventually become cultural values when students mature. Teachers 'religious attitudes and behavior towards differences in ethnicity and religious beliefs can influence students' religious attitudes and behavior when these attitudes and behaviours are intensively taught to students. Likewise, the nationalism possessed by the teacher can trigger the emergence of nationalism in students or vice versa.

As a multicultural country, Indonesia faces a difficult problem in managing the state ideology, politics, economy, society, and culture, especially in the transition phase of democracy. The democracy transition phase or consolidating democracy which is 'critical juncture' [1][2], raises new problems, namely, along with the openness of the social and political system and the freedom of opinion and association, both in the social, political, individually and in groups, various transnational Islamic ideologies, beliefs and ideologies have entered. The rush of this transnational ideology collides with the established belief system in society because it is radical, exclusive, anti-difference, and likes to accuse others as kafir (non-Muslim) even to Muslims - to beliefs that justify acts of terror to achieve their ideological goals. 
The strength of transnational and radical Islamic ideological movements in Indonesia is not only their strong network [3], but Indonesia itself is a fertile place for their movements to flourish [4]. This means that the Indonesian people themselves welcome the presence of radical Islamic movements from outside, even though a study shows, compared to Malaysia alone, Indonesia is more at risk of facing the attack of radical Islam from the Middle East [5]. A condition that is certainly dangerous for the survival of the Indonesian nation considering that sociologically Indonesia consists of various ethnicities and religions so that the radical Islamic movement has the potential to break the unity that has been built. On that basis, it is important to have a view and attitude that can strengthen nationalism, including an attitude of respecting differences in ethnicity, differences in religion and commitment to state ideology and the form of the state.

This article describes the attitude of Islamic religious teachers in Central Java in seeing differences in ethnicity and beliefs. Sourced from the results of research with a quantitative approach through a survey spread across 14 regency/municipals in Central Java, with a total of 45 respondents of Islamic Religion teachers from public and private high schools and vocational schools (the number of populations is not precisely unknown), using proportional random sampling.

\section{Result and Discussion}

The study of the relationship between a person's attitude both as an individual and as a group member and their behavior is very important to know. Scholars, especially social psychology, have put this issue in their studies as an attempt to unravel the complexity of human behavior. The complexity of this behavior causes the relationship between attitude and behavior to be inconclusive. Some studies have shown a very strong relationship between the two (see, for example, Ajzen [6] and Eiser [7]). However, some studies concluded that the relationship was very weak [8]. To bridge these two views, Warner and De Fleur In Azwar [8] proposed three postulates, namely postulate of consistency, the postulate of independent variation, and the postulate of contingent consistency. The consistency postulate explains that a person's verbal attitude is an accurate guide to predict behavior. The independent variation postulate assumes that attitude and behavior are two independent things in each individual, knowing a person's attitude does not mean that the behavior is predictable. The dependent consistency postulate explains that the relationship between attitude and behavior is largely determined by certain situational factors, where these situations can change the relationship between attitudes and behavior. Dependency conditions that change the relationship between attitudes and behaviours include norms that live and are recognized in society, the role of individuals in groups, culture, and religious beliefs. In this context, the study of attitudes and behavior develops into various dimensions, including the religious dimension. Several studies that examine the psychology of religion from the perspective of attitudes and behavior, such as Agniezka et al. [9], which in their study found, among others, the fact that interreligious friendships reduce negative attitudes towards the religious out-group. Conversely, casual interreligious contact increases negative out-group attitudes. This field finding also states that someone who has experience of interfaith violence has a more negative attitude than those who do not. Even so, this experience of interreligious violence did not affect the interreligious friendship among them, but it was quite influential on their casual interreligious contact.

Sociologically, most high school Islamic teachers in Central Java are groups of people who live in ethnic diversity, this can be seen from 60 percent of Islamic teachers have friends or 
neighbours of different ethnicities. In this study, all respondents were Javanese Islamic teachers, a condition that reflects the reality where almost all Islamic teachers in Central Java come from Javanese ethnicity.

Based on these sociological conditions, the results of the study showed that the majority of respondents, namely 97.8 percent, stated that they were willing to be friends or neighbours with people of different ethnicities. This shows that Islamic high school/vocational school teachers in Central Java have an open attitude in accepting ethnic differences in daily life.

A different attitude is shown when the respondents are faced with the domination of other ethnicities on economic or political life in Indonesia, where there is 20 percent of Islamic religion teachers who think that there are other ethnicities that are dominant in economic life in Indonesia. Trust in figures who come from the same or different ethnicities also illustrates attitudes towards ethnic differences. In this case, the majority, namely 62.2 percent, indicated that even against figures from other ethnicities they still believed. Although later in this aspect, 35.6 percent believed more on figures from the same ethnicity.

Acceptance of leaders who come from other ethnic groups is an important aspect of a heterogeneous society. Willingness to accept leaders from other ethnicities can encourage a harmonious social life. The results showed that from three levels of leadership, namely the Regent/Mayor as a leader in the regency/city scope, the Governor as a leader in the province and the president as a national leader illustrates that at a higher level, the level of disapproval of other ethnicities becomes bigger.

The diversity of people ethnically as a sociological condition of the Indonesian nation makes living in different tribes as a norm or in other words a feeling of comfort when amid different ethnicities should be an expected condition. Regarding this reality, the majority of Islamic Religion teachers, namely 91 percent feel comfortable when they are in the middle of different ethnicity, while 6.6 percent feel uncomfortable when they are in a different ethnic group.

Table 1. Attitude Towards Different Ethnicity

\begin{tabular}{|c|c|c|c|c|c|}
\hline \multirow{2}{*}{ Indicators } & \multicolumn{5}{|c|}{ Views and Attitudes } \\
\hline & SD & $\mathbf{D}$ & $\mathbf{A}$ & $\mathbf{S A}$ & $\mathbf{N}$ \\
\hline $\begin{array}{l}\text { Do not want to be friends with people of different } \\
\text { ethnicities }\end{array}$ & 75,6 & 22,2 & 0 & 0 & 2,2 \\
\hline $\begin{array}{l}\text { The existence of other ethnicities is dangerous for } \\
\text { society }\end{array}$ & 68,9 & 26,7 & 2,2 & 0 & 2,2 \\
\hline $\begin{array}{l}\text { Other ethnic groups dominate the economy and } \\
\text { politics in Indonesia }\end{array}$ & 20 & 57,8 & 15,6 & 4,4 & 2,2 \\
\hline More trust with figures from the same ethnicity & 8,9 & 53,3 & 26,7 & 8,9 & 2,2 \\
\hline Different ethnicities become regents/mayors & 6,7 & 17,8 & 71,1 & 2,2 & 2,2 \\
\hline Different ethnicities became governors & 0 & 22,2 & 71,1 & 4,4 & 2,2 \\
\hline Different ethnicity become President & 0 & 26,7 & 62,2 & 8,9 & 2,2 \\
\hline Feel uncomfortable in a different ethnic group & 15,6 & 75,6 & 4,4 & 2,2 & 2,2 \\
\hline $\begin{array}{l}\mathrm{SD}=\text { Strongly disagree } \\
\mathrm{SA}=\text { Strongly agree }\end{array}$ & nsv & & $\mathrm{A}=$ & & \\
\hline
\end{tabular}

Differences in religion and belief are a natural condition in a society consisting of various religions. The views and attitudes to be able to accept these different beliefs are needed in the hope of being able to create harmonious social conditions. The results showed that the majority 
of SMA/SMK Islamic teachers in Central Java lived in a diversity of beliefs. 89.9 percent of them had friends or neighbors of different religions (non-Muslims).

In general, all Islamic religious teachers are a group of people who can accept different beliefs. This can be seen from all respondents who live next door to non-Muslim residents, even though in reality there is 11.1 percent who do not have non-Muslim neighbors. Likewise, the willingness to assist non-Muslims who have a bad situation where all respondents are willing to assist.

Table 2. Attitude Towards Different Faith

\begin{tabular}{|l|c|c|c|c|c|}
\hline \multirow{2}{*}{\multicolumn{1}{|c|}{ Indicators }} & \multicolumn{5}{|c|}{ Views and Attitudes } \\
\cline { 2 - 7 } & SD & D & A & SA & N \\
\hline $\begin{array}{l}\text { Establishment of places of worship for non-Muslim in } \\
\text { their neighborhood }\end{array}$ & 4,4 & 35,6 & 53,3 & 0 & 6,7 \\
\hline Giving greetings on holidays to non-Muslims & 8,9 & 40 & 48,9 & 2,2 & 0 \\
\hline Non-Muslim residents become regents/mayors & 11,1 & 46,7 & 0 & 33,3 & 8,9 \\
\hline Non-Muslims become governors & 8,9 & 51,1 & 0 & 31,1 & 8,9 \\
\hline Non-Muslims become president & 13,3 & 55,6 & 0 & 22,2 & 8,9 \\
\hline
\end{tabular}

Different views and attitudes can be seen on the attitude on the issue of the worship places construction in their neighbourhood. Although the majority (53.3 percent) of Religion teachers agree with the establishment of houses of worship by non-Muslims, there are different views where 40 percent disagree and strongly disagree.

Similar conditions can be seen in responding to the holiday celebrations of non-Muslim residents, 48.9 percent of Islamic religious teachers disagree and strongly disagree in giving greetings to non-Muslims on holidays.

Table 3. Willingness to Cooperate with Non-Muslim Citizens

\begin{tabular}{|l|c|c|}
\hline \multicolumn{1}{|c|}{ Indicators } & \multicolumn{2}{c|}{ Views and Attitudes } \\
\cline { 2 - 3 } & Will & Unwilling \\
\hline $\begin{array}{l}\text { Willingness to cooperate with non-Muslims in } \\
\text { social activities }\end{array}$ & 100 & 0 \\
\hline $\begin{array}{l}\text { Willingness to cooperate with non-Muslims in } \\
\text { economic activities }\end{array}$ & 97,8 & 2,2 \\
\hline $\begin{array}{l}\text { Willingness to cooperate with non-Muslims in } \\
\text { political activities }\end{array}$ & 80 & 20 \\
\hline
\end{tabular}

Different views and different attitudes are shown on the willingness to cooperate in the social, economic, and political fields with non-Muslim citizens or groups. The results showed that in the social sector all respondents stated their willingness to cooperate with non-Muslim citizens or groups, however, in the economic and political fields the percentage of their unwillingness was bigger. As many as 2.2 percent of respondents stated that they do not want to cooperate in the economic sector and in the political field as many as 20 percent of the respondents stated not willing.

Such views and attitudes are in line with the approval of non-Muslim citizens or groups to become leaders at the city/district, provincial and national levels. The large percentage of unwillingness to work in the political field is accompanied by the disapproval of non-Muslims to become regents/mayors, governors, and presidents where the majority of respondents (57.8 percent) expressed their disapproval of non-Muslim citizens becoming regents/mayors in their 
neighborhood. Likewise, 60 percent expressed their disapproval when a non-Muslim citizen became governor of Central Java, and 68.9 percent expressed disapproval when a non-Muslim becomes president.

Amid diverse ethnicity and religious beliefs, ideology and the form of the state have become problems that have emerged with the radicalism movement that has developed especially among youth. The Islamic Religion teachers have a role in providing understanding and awareness for students about the importance of maintaining Pancasila as the state ideology and NKRI as a form of the state.

The results showed that the form of the state "NKRI" and Pancasila as the state ideology, was seen by the majority of Islamic religious teachers as the most ideal and final. However, there is still 2.2 percent of teachers who think that NKRI is not the best form of state. Likewise, with Pancasila as the state ideology, where 2.2 percent of Islamic religious teachers think that Pancasila is not the most appropriate ideology for the Indonesian nation.

\section{Conclusion}

The majority of high school Islamic Religion Teachers in Central Java are groups of people who live in ethnic diversity and religion or belief. They have views and attitudes that can accept ethnic differences, are willing to cooperate, have high trust in others even though they are of different ethnicities, and the ability to build a harmonious social life with different ethnicities.

They have views and tolerant attitudes towards different beliefs. The willingness to live next door, cooperate, help, attend invitations from non-Muslims is an indicator of this tolerant and cooperative attitude. They even consider non-Muslim people to be part of their national family. However, in the political field, there are different views and attitudes with a large enough percentage not to be willing to cooperate. It is reinforced by the views and attitudes of their disapproval of non-Muslims who become regents/mayors, governors, or presidents in their respective regions.

This is because the majority of them have the views and attitudes of a nationalist who believes that Pancasila and NKRI are the most appropriate ideologies and forms of state for Indonesia. However, there are still religious teachers who think that Pancasila and NKRI are not the most appropriate ideologies and forms of state for Indonesia, they think that the Khilafah is the right concept to be applied in Indonesia.

\section{References}

[1] Aspinall; Fealay, Soeharto's new order and its legacy, essays in honour of Harold crouch. ANU E Press, 2010.

[2] E. Aspinall, "Ethnic and religious violence in Indonesia: a review essay," Aust. J. Int. Aff., vol. 62 , no. 4 , pp. 558-572, 2008.

[3] I. Gul, "Trans Islamic Network," Int. Rev. Red Cross, vol. 92, no. 880, pp. 899-923, 2010.

[4] F. Greg, "Islamic Radicalism in Indonesia: the Faltering Revival?," Southeast Asian Aff. Inst. Southeast Asian Stud. Singapura, 2004.

[5] O. B. K. Yusoff, "Islamic Radicalism in Malaysia: An Overview," Procedia Soc. Behav. Behav. Sci., vol. 5, pp. 2326-2331, 2010.

[6] Ajzen I., Attitudes, Personality and Behavior. New York: Open University Press, 2005.

[7] J. R. Eiser, Social Psychology: Attitudes, Cognition and Social Behavior. New York: Cambridge University Press, 1986.

[8] Azwar S., Sikap Manusia: Teori dan Pengukurannya. Yogyakarta: Pustaka Pelajar, 2013. 
[9] S. Agniezka Kanas and C. Peer Sterkens, "Religious identification and interreligious contact in Indonesia and the Philippines: Testing the mediating roles of perceived group threat and social dominance orientation and the moderating role of context," Eur. J. Soc. Psychol., vol. 46, no. 6, pp. 700-715, 2016. 